\title{
The Relevance of Organizational Characteristics for Crisis Planning
}

\author{
Kerstin Bremser ${ }^{1}$, María del Mar Alonso-Almeida ${ }^{2} \&$ Véronique Göhlich ${ }^{1}$ \\ ${ }^{1}$ Hochschule Pforzheim, Tiefenbronner Str. 65, 75175 Pforzheim, Germany \\ ${ }^{2}$ Universidad Autónoma de Madrid, Ciudad Universitaria de Cantoblanco, 28049 Madrid, Spain \\ Correspondence: Kerstin Bremser, Hochschule Pforzheim, Tiefenbronner Str. 65, 75175 Pforzheim, Germany. Tel: \\ 49-7231-286-299. E-mail: Kerstin.Bremser@hs-pforzheim.de
}

Received: November 14, 2014

Accepted: December 5, 2014

Online Published: December 9, 2014

doi:10.5430/bmr.v3n4p26

URL: http://dx.doi.org/10.5430/bmr.v3n4p26

Earlier versions of this article were presented at the 2014 TMS Algarve Conference in Olhão, Portugal, the 2014 Global World Business Conference in Tignes, France and the 2013 Euromed Conference in Estoril, Portugal. We thank the conference participants for their valuable comments.

\begin{abstract}
The purpose of the research was to investigate the readiness of the touristic branch for facing economic and financial crisis. The paper is based on a study undertaken in the Madrid region in 2009.

Predictors of crisis including gender have been surveyed for a total of 198 hotels and 291 restaurants in the province of Madrid. The study demonstrated that the age and size of the decision-making organization and the gender of the business' leader did influence crisis planning. Major differences were found between hotels and restaurants, the last ones being more severely affected than hotels and thus placing more emphasis on planning ahead. Age was an indicator of the existence of "soft" crisis planning tools. Size was an indicator only for restaurants. Gender of the business owner also influenced crisis planning.

Recommendations for policy makers on which types of owners they need to focus on for giving assistance in time of crisis were made. The scope of the study was geographically very limited and would need to be expanded to further parts of Spain or to other countries with strong tourism activities.
\end{abstract}

Keywords: Crisis management, Crisis planning, Spain, Tourism, Financial crisis

\section{Introduction}

The study examines the Spanish tourism industry, particularly its hotels and restaurants, during the last financial crisis. The crisis started with the fall of Lehman Brothers in September 2008 and subsequently spread around the globe. Initially, Spain was not touched by the crisis because its banks had abstained from purchasing complex financial products (Taylor, 2009). However, when the global money supply decreased and banks stopped lending, Spain was affected and suffered a severe economic downturn. The country's housing bubble burst, employment in the construction industry deteriorated, tourists stayed away and spending fell (NN, 2009). Because tourism and construction are major contributors to Spain's GNP (together with the related transport sector, they represented nearly $20 \%$ of the $2008 \mathrm{GNP}$ ), with their decline, the entire economy went into recession (NN, 2010). Thus, hotels and restaurants were also affected by the financial crisis. The Spanish are fond of their country, and domestic tourists represent an important income source for Spanish hotels. In addition, the Spanish like to spend time outdoors and frequently meet in bars or restaurants, thus increasing restaurant income (Graf-Riemann, 2011).

This study has two objectives: The literature on crisis planning in the services sector focuses primarily on hotels and rarely on restaurants. Because these businesses are related, the study's first objective is to compare the differences in crisis planning at the two business types. The results will enable restaurant managers to benefit more from actions undertaken in the hotel business and vice versa. A second objective is to intensify research on how organizational characteristics influence crisis planning. Whereas prior research exists on organization age and size, gender has rarely been examined. Thus, policy makers will be able to better tailor help and foster innovation (which is needed in crisis-hit regions) to certain groups of businesses.

The remainder of the article is structured as follows: section two presents a brief literature review followed by an 
explanation of the method employed in section three. In section four, results will be presented. The results are discussed in section five, in which conclusions are drawn and future lines of research are suggested.

\section{Overview of the Literature}

\subsection{Elements of Crisis Management}

Crisis and critical events have been discussed in a large number of studies in the business literature. Faulkner (2001) presents a review of the literature on the theory of crisis and disasters. Faulkner summarizes these studies and defines "crisis" based on the presence of the following characteristic features:

- "a triggering event"

- "high threat, short decision time and an element of surprise and urgency"

- "a perception of an inability to cope among those directly affected"

- "a turning point, when decisive change ... is imminent"

- “'fluid, unstable, dynamic' situations" (Faulkner, 2001, p. 138).

The terms "crisis" and "disaster" are often used simultaneously. For an organization, their consequences are highly similar. They only differ according to their root cause. Henderson (2007) categorizes crises into six different types, which can be observed in their effects on the tourism industry: economic, political, socio-cultural, environmental, technological or commercial crises that are caused by external or internal factors. Of these different types of crisis, in Madrid or Spain as a whole, four types have been experienced in recent years: environmental (with the two subtypes disaster and health threat, i.e., the volcanic eruption in Iceland that brought all air traffic over Europe to a standstill for several weeks and the outbreaks of SARS or avian influenza, respectively), political (the Madrid Metro bombings in March 2004 and ETA terrorist attacks) and economic (the collapse of Lehman Brothers or the Euro crisis). Obviously, the critical events did not originate in the tourism industry but affected tourism as a consequence (e.g., the decrease in travel or, more generally, spending). Because crises occur often and for many different reasons, it is no longer a question whether a business will be adversely affected by a crisis but when (Kash \& Darling, 1998). Thus, the tourism industry must prepare for crises as much as any other industry involved in international commerce. However, the literature abounds with reports on the lack of crisis planning in the tourism industry (Henderson, 1999, Sausmarez, 2004, Okumus \& Karamustafa, 2005, Anderson, 2006, González-Herrero \& Pratt, 2007).

\subsection{Types of crisis}

As mentioned above, only four types of crisis have been observed in Madrid, Spain, in recent years. These crises affected businesses differently, often only through side effects. Political crises in the form of terrorist attacks aim to threaten ordinary individuals and affect public life. Often, visitors fear terrorist attacks and will not travel to a certain destination. Already planned trips will be cancelled, particularly if travel warnings by foreign governments have been issued. As Pizam \& Fleischer (2002) noted, these effects will be brief if the response of the authorities is considered to be adequate. Health scares, i.e., SARS or avian influenza, force governments to issue travel bans on visitors from affected countries. Particularly in the case of SARS, the responses of European governments have been severe. Switzerland closed an international trade fair to Asian visitors and exhibitors for fear of spreading the disease (Messe Basel, 2003). Experience indicates that a sudden decrease in visitors will leave hotels and restaurants badly prepared, and government action is required to reestablish trust in a region in which such an event has occurred (Johnson Tew et al. 2008). Environmental crises (e.g., the Indonesian tsunami) might destroy entire tourist destinations or restrict travel severely (e.g., the restrictions on air travel because of the Icelandic or Chilean volcanic eruptions). However, in this area, Spain has not been as badly affected as countries that are located in more disaster-prone areas.

In particular, businesses fear economic crisis in the form of a recession. In Spain, where the recent financial crisis damaged the country's image severely and caused a decline in tourism, this fear is not surprising (Vargas-Sánchez, 2014). In addition, financial advisors have advised businesses for many years that provisions must be made for difficult periods. Small businesses even define crises as events that affect company cash flow, neglecting their causes (Herbane, 2010). Given that the Lehman Brothers collapse, which is considered to be the beginning of the 2008-2009 global crisis, was well publicized and stock market reactions were visible immediately, the awareness of an upcoming crisis increased. Thus, a first hypothesis is postulated:

H1: The businesses that fear an economic crisis most are less concerned about other critical events. 


\subsection{Organizational Characteristics - Size}

The question remains whether certain organizational characteristics, particularly an organization's size or age or the gender of the person in charge, encourage crisis planning. The literature in this area, which commenced with a study by Reilly (1987), is scant. Reilly created a new construct termed "crisis readiness," which includes crisis response ability, information on the crisis, the availability of crisis plans, strategic crisis planning, media management during a crisis and the likelihood of the organization being struck by a crisis. Reilly's exploratory study covered several industries and included service industries. She determined that larger organizations are better prepared for a crisis than smaller ones. Reilly's results were confirmed for the tourism sector by Johnson Tew et al. (2008). Johnson Tew et al. (2008) focused on the tourism industry in Toronto, Canada, during the SARS outbreak and noted that in particular, hotels that belong to large chain organizations, e.g., Accor or Marriot, received detailed information on how to address the crisis, whereas smaller establishments were restricted to information from the government, which initially did not regard the outbreak as serious. More recent studies were conducted by Pennington-Gray et al. (2011), who surveyed different segments of the US tourism industry with respect to crisis preparedness. Here, resource allocation in the form of money or personnel strongly correlated with the existence of crisis plans or membership in crisis warning associations. Because businesses such as owner-managed hotels or restaurants are typically smaller than their chain-owned counterparts, size obviously increases crisis readiness. When examining SME in general, "[...] small businesses with their limited resources are especially vulnerable to the catastrophic consequences of crisis events" (Spillan \& Hough, 2003, p. 406). In addition, Herbane (2010) confirmed the lesser degree of crisis readiness of SMEs compared with large businesses. Naidoo (2005) stressed the importance of marketing innovation in Chinese SME for crisis survival. SME with their limited resource can only successfully withstand a crisis if they own a competitive advantage based (mostly) on marketing innovations.

Thus, the second hypothesis can be stated:

$\mathrm{H} 2$ : Larger businesses are better prepared for a financial crisis than smaller ones.

\subsection{Organizational Characteristics - Age}

In addition to size, age is also frequently mentioned in connection with crisis readiness. Often, older businesses have survived a crisis in the past and are thus more likely to create crisis plans. Reilly (1987) found weak evidence that past crisis experience was positively correlated with having a crisis plan in place. Pennington-Gray et al. (2011) found evidence for the North-American tourism industry that previous crisis experience encouraged organizations to invest in future crisis planning. Rodriguez-Toubez et al. (2012) observed that crisis experiences might encourage formal crisis planning. However, given that crises differ, one experience of a crisis might not be applicable to the next crisis. Many studies in the tourism sector do not examine crisis situations but investigate general hotel or restaurant survival rates. Parsa et al. (2005) stated that age is positively correlated with survival. Given that critical situations occur frequently, age implies that a hotel or restaurant has previously successfully survived a crisis. Thus, a third hypothesis can be stated:

H3: Older businesses are better prepared for a financial crisis than younger ones.

\subsection{Organizational Characteristics - Gender}

Regarding gender and crisis, scant evidence exists. However, research on business success and gender is readily available. Diéguez Castrillón et al. (2010) researched female success in rural tourism establishments in Portugal. They detected that in general, women are more successful than men if financial and employment measures are combined. This finding is similar to one by Alonso-Almeida \& Bremser (2014), who researched travel agencies in Spain with respect to their strategic decisions in crisis periods. They detected that whereas men and women are similarly successful in surviving a crisis, women prefer to rely on "soft" measures in their responses. Often, crisis management depends on the soft-leadership skills that are typically attributed to women. However, society often hinders women in acting as leaders in crisis situations, thus rendering more successful crisis management difficult (Gartzia et al., 2012). Therefore, the third hypothesis is as follows:

H4: Female-led businesses are better prepared for a financial crisis than male-led ones.

\section{Methodology}

The data were collected in October 2009 using a personal survey. Interviewers contacted hotel and restaurant owners or managers. In total, 291 Madrid restaurants were surveyed, and 180 valid responses were collected (a response rate of $62 \%$ ), which represents a high response rate for this type of study. 19 restaurants were led by female managers or owners (6.5\%). In addition, 198 hotels were contacted, of which 134 responded (a response rate of $68 \%$ ), 53 of them with female 
leadership (39.5\%). Hotels and restaurants listed in the Tourspain Guide were chosen for the survey. The study was performed in Madrid because the city benefits equally from domestic and international business travelers and tourists. In addition, the Madrid results could be compared with those for other Southern European capitals that enjoy a similar status (e.g., Lisbon or Rome). The research was conducted as a descriptive analysis. The 180 restaurants in the sample were on average 18.3 years old and had a seating capacity of 114 seats, which is above the national average (Fundación Hostelería de Espana, 2013). The hotels were on average younger: 16.5 years old. They had a median capacity of 175 beds, which is also above the national average (Fundación Hostelería de Espana, 2013). Because Madrid is Spain's economic and political capital with large conference centers and the headquarters of many national and international firms, it is not surprising that hotels and restaurants tend to be larger than in the country as a whole.

\section{Results}

To verify hypothesis 1 (The businesses that fear an economic crisis most are less concerned about other critical events), the respondents were asked to mark which of the following items they considered to be most damaging for their company: a recession, a terrorist attack, an epidemic or a natural disaster. The questionnaire did not rely on the wording of Henderson (2007) because it was judged that the respondents would be more familiar with specific examples than general terms and because the questions were restricted to events that had occurred in Madrid province. Next, the answers were correlated using Pearson's correlation coefficient. The results of the analysis can be found in tables 1 and 2.

Table 1. Hotels - importance of critical events

\begin{tabular}{lll}
\hline Event & Percentage* & Pearson's correlation coefficient \\
\hline Recession & 77 & \\
Terrorist Attack & 26 & $-0.455^{* *}$ \\
Epidemic & 10 & $-0.239^{* *}$ \\
Natural Disaster & 20 & $-0.267^{* *}$ \\
\hline
\end{tabular}

* several answers possible

**statistically significant at the 0.01 level

Source: Authors

Table 2. Restaurants - importance of critical events

\begin{tabular}{lll}
\hline Event & Percentage* & Pearson's correlation coefficient \\
\hline Recession & 83 & \\
Terrorist Attack & 7 & $-0.336^{* *}$ \\
Epidemic & 12 & $-0.348^{* *}$ \\
Natural Disaster & 12 & $-0.441^{* *}$ \\
\hline
\end{tabular}

* several answers possible $\quad * *$ statistically significant at the 0.01 level

Source: Authors

In both cases, recessions are feared most by the businesses, and this fear is statistically significant and negatively correlated with the fear of other forms of crisis. In addition, the interviewees stated that recessions last longer and affect a business more severely than other critical events. Thus, the hypothesis was fully supported.

Hypothesis 2 (Larger businesses are better prepared for a financial crisis than smaller ones) was tested by asking the respondents how much they agreed with several statements regarding crisis planning. A 5-point Likert scale was used with 5 representing complete agreement. The answers were correlated with the size of the businesses. The results are presented in table 3. Statements were not restricted to the existence of a crisis plan only because several authors emphasized that a formal plan is just one element of a successful crisis management strategy (Rodriguez-Toubez et al., 2012, Reilly, 1987). 
Table 3. Correlation Size - crisis planning

\begin{tabular}{lll}
\hline Statement & Correlation coefficient Hotel & Correlation coefficient Restaurant \\
\hline $\begin{array}{l}\text { The company possesses an anti-crisis plan } \\
\begin{array}{l}\text { The company prepared for the crisis by } \\
\text { taking internal measures }\end{array}\end{array}$ & 0.154 & $0.229^{* *}$ \\
$\begin{array}{l}\text { The company has experienced another } \\
\text { crisis and survived }\end{array}$ & 0.109 & $0.161^{* *}$ \\
$\begin{array}{l}\text { The company learned from another crisis } \\
\text { and made adjustments within the }\end{array}$ & 0.013 & $0.204^{*}$ \\
organization &
\end{tabular}

*statistically significant at the 0.05 level ${ }^{* *}$ statistically significant at the 0.01 level

Source: Authors

In the case of restaurants, the hypothesis is clearly supported. Larger restaurants possess crisis plans, prepare ahead and have previously experienced critical situations. Surprisingly, the case for hotels is different. No correlation is significant. In sum, this outcome results in a partial acceptance of the hypothesis.

To test hypothesis 3 (Older businesses are better prepared for a financial crisis than younger ones), the same method was used as for size. The results are displayed in table 4.

Table 4. Correlation Age - crisis planning

\begin{tabular}{lll}
\hline Statement & Correlation coefficient Hotel & Correlation coefficient Restaurant \\
\hline $\begin{array}{l}\text { The company possesses an anti-crisis } \\
\text { plan }\end{array}$ & 0.102 & 0.135 \\
$\begin{array}{l}\text { The company prepared for the crisis by } \\
\text { taking internal measures }\end{array}$ & 0.125 & 0.070 \\
$\begin{array}{l}\text { The company experienced another crisis } \\
\text { and survived }\end{array}$ & $0.169^{*}$ & $0.178^{*}$ \\
$\begin{array}{l}\text { The company learned from another crisis } \\
\text { and made adjustments within the }\end{array}$ & 0.109 & $0.161^{*}$ \\
organization & & \\
\hline
\end{tabular}

*statistically significant at the 0.05 level

Source: Authors

Here, learning from a past crisis was statistically significant for hotels and restaurants, whereas the previous experience of a crisis was only significant in the case of restaurants. Therefore, the hypothesis is partially supported.

Hypothesis 4 (Female-led businesses are better prepared for a financial crisis than male-led ones) was tested using the entire sample of hotels and restaurants because only a few hotels and restaurants were female-led. First, the correlation coefficients were calculated. Second, the quadratic sum method was used to test for inter- and intra-group difference between male and female respondents. The results for the entire sample are displayed in tables 5 and 6 .

Table 5. Correlation Sex - crisis planning

\begin{tabular}{|c|c|}
\hline Statement & Correlation coefficient \\
\hline The company possesses an anti-crisis plan & 0.071 \\
\hline $\begin{array}{l}\text { The company prepared for the crisis by taking internal } \\
\text { measures }\end{array}$ & 0.056 \\
\hline The company experienced another crisis and survived & $-0.120^{*}$ \\
\hline $\begin{array}{l}\text { The company learned from another crisis and made } \\
\text { adjustments within the organization }\end{array}$ & -0.204 \\
\hline \multicolumn{2}{|l|}{ *statistically significant at the 0.05 level } \\
\hline \multicolumn{2}{|l|}{ Source: Authors } \\
\hline Published by Sciedu Press & ISSN 1927-6001 \\
\hline
\end{tabular}


Table 6. Quadratic Sum - inter- and intra-group differences between sexes

\begin{tabular}{|c|c|c|c|c|c|c|}
\hline Statement & & Quadratic Sum & $\mathrm{Gl}$ & Quadratic Mean & $\mathrm{F}$ & Sig. \\
\hline \multirow{3}{*}{$\begin{array}{l}\text { The company } \\
\text { possesses an anti-crisis } \\
\text { plan }\end{array}$} & Inter-group & 5.774 & 1 & 5.774 & 1.888 & 0.170 \\
\hline & Intra-group & 1128.253 & 369 & 3.058 & & \\
\hline & Total & 1134.027 & 370 & & & \\
\hline \multirow{3}{*}{$\begin{array}{l}\text { The company prepared } \\
\text { for the crisis by taking } \\
\text { internal measures }\end{array}$} & Inter-group & 2.780 & 1 & 2.780 & 1.177 & 0.279 \\
\hline & Intra-group & 871.237 & 369 & 2.361 & & \\
\hline & Total & 874.016 & 370 & & & \\
\hline \multirow{3}{*}{$\begin{array}{l}\text { The company } \\
\text { experienced another } \\
\text { crisis and survived }\end{array}$} & Inter-group & 17.147 & 1 & 17.147 & 5.403 & 0.021 \\
\hline & Intra-group & 1171.020 & 369 & 3.173 & & \\
\hline & Total & 1188.167 & 370 & & & \\
\hline \multirow{3}{*}{$\begin{array}{l}\text { The company learned } \\
\text { from other crisis and } \\
\text { made adjustments } \\
\text { within the organization }\end{array}$} & Inter-group & 1.304 & 1 & 1.304 & 0.461 & 0.498 \\
\hline & Intra-group & 1043.629 & 369 & 2.828 & & \\
\hline & Total & 1044.933 & 370 & & & \\
\hline
\end{tabular}

Here, experience of a previous crisis was negatively correlated with survival. However, since there are no statistically significant results from the analysis of quadratic sums, the hypothesis has to be rejected.

\section{Discussion of Results}

As shown in the statistical analysis that appears in the results section (section 4), H1 (The businesses that fear an economic crisis most are less concerned about other critical events) is fully supported for both business groups. This outcome is not surprising. Recessions are part of the economic cycle, and most individuals have experienced recessions. Additionally, business advisors warn of recessions, and business schools teach that companies should make provisions for emergencies. Other types of crises occur sporadically and spontaneously and are often limited to certain geographical regions. Furthermore, as Enz et al. (2011) demonstrates in a discussion of the 9/11 terrorist attacks and recessions, recessionary effects typically last longer.

Surprisingly, H2 (Larger businesses are better prepared for a financial crisis than smaller ones) was only supported in the case of restaurants. For hotels, the results exhibited no significance. In the case of larger businesses, they typically possess substantial resources, which can be used in a crisis or to invest in strategic management departments. In addition, chain restaurants can often rely on knowledge provided by company headquarters. It is not clear from the data if larger hotels or restaurants inevitably belong to a chain or if size is independent of ownership structure. Thus, it could be that instead of size, chain ownership is the decisive factor.

Hypothesis 3 (Older businesses are better prepared for a financial crisis than younger ones) also finds only partial support. Given that many hotels and restaurants are privately owned and owners often do not possess a conventional education in business, formal methods do not indicate crisis readiness as well as informal ones. Based on the questionnaires, prior crisis experience is the decisive factor, not the existence of formal planning tools. This finding agrees with the literature.

Hypothesis 4 (Female-led businesses are better prepared for a financial crisis than male-led ones) had to be rejected. Because the literature on the subject is scarce, no comparison with other studies could be performed. However, the results demonstrate that fewer women answer the question regarding previous crisis experience affirmatively. Because women generally have less experience in leadership positions and their businesses are often younger, this finding agrees with the literature.

\section{Conclusion}

At the paper's beginning, two research objectives were presented. First, the differences between hotels and restaurants should be analyzed. Based on the results, major differences can be found between hotels and restaurants. Whereas both types of business display an equal fear of financial crises, their responses toward a recession differ. 
Restaurants seem to engage more often in formal crisis planning. Given that both types of business operate in the same segment of the economy and are often referred to together, the results demonstrate that differences should be considered. In financial crises, individuals first eliminate purchases or behaviors considered to be luxurious or unnecessary (Ang et al., 2000). Dining out can be easily replaced by eating at home, forgoing meals or using cheaper sources (e.g., bakeries or snack stalls). In contrast, research has demonstrated that during recessions, individuals often do not cancel travel plans but instead shorten or downgrade them (Barsky, 2009). Vacations are often booked and paid for in advance, and business trips are still needed to visit customers or providers. Moreover, hotels possess more options to create income or decrease costs (i.e., opening their spa, gym and pool facilities to locals, promoting their facilities to locals for family events or closing parts of the facility). These findings indicate that restaurants might be first and more severely affected than hotels in a financial crisis and thus place more emphasis on planning ahead. Here, hotels can learn from the restaurant business by copying their planning tools.

The second objective was to determine if organizational characteristics indicate the existence of crisis planning. Again, differences appear between hotels and restaurants. For both types of business, age is at least an indicator of the existence of "soft" crisis planning tools. Size is an indicator only for restaurants. For both types of business, the female gender of the business owner indicates less experience of crisis and subsequently less crisis planning. This finding is important for policy makers. To increase awareness in such businesses, programs directed at younger or female-led businesses are required. Older or male-led establishments appear to be better prepared. Additionally, research suggests that businesses led by gender diverse teams are more successful than single gender teams (McKinsey \& Company, 2013). Here, it might be innovative to create deliberately mixed leadership teams in order to improve results.

Furthermore, the paper contributes also to help counselors and policy makers. If, in larger studies, age, size and gender determine the existence of crisis management the data could be used to identify companies that benefit from specific counselling. Many chambers of commerce collect these data from their members and could thereby improve their offerings. Also, policy makers that offer specific incentives for certain types of companies (i.e. female-led, entrepreneurial, new creation ...) could include in their requirements for receiving funding or subsidies the existence of crisis management if the company falls under the definition of being at risk.

These conclusions should be viewed cautiously. The study only examines a small part of Spain at a single point in time. Also, results have not been cross-checked for cultural parameters. Longitudinal studies or studies that examine a wider geographic area will deliver sounder results. In particular, the differences between hotels and restaurants are worthy of further research. In addition, the issue of gender should also be investigated in other industries to test its validity.

\section{References}

Alonso-Almeida, M. M.; Bremser, K. (2014). Management decisions in crisis times: a gender perspective. ttem 9 (1), $43-50$.

Anderson, B. A. (2006). Crisis management in the Australian tourism industry: Preparedness, personnel and postscript. Tourism Management 27, 1290-129. http://dx.doi.org/10.1016/j.tourman.2005.06.007

Ang, S. H. A.; Leong, S. M.; Kotler, P. (2000). The Asian Apocalypse: Crisis Marketing for Consumers and Businesses. Long Range Planning, 33, 97-119. http://dx.doi.org/10.1016/S0024-6301(99)00100-4

Aterido R. and Hallward-Driemeier, M. (2011). Whose business is it anyway? Closing the gender gap in entrepreneurship in Sub-Saharan Africa. Small Business Economics, 37, 443-464. http://dx.doi.org/10.1007/s11187-011-9375-y

Barsky, J. (2009): Luxury hotels and recession: a view from around the world. Market Metrix. CA.

Diéguez Castrillón, M. I.; Gueimonde Canto, A.; Sinde Cantorna, A. I. (2010): Éxito empresarial y género en turismo rural. Tourism \& Management Studies 6, 82-93.

Enz, C. A.; Kosová, R.; Lomanno, M. (2011). The impact of terrorism and economic shocks on U.S. hotels. Cornell Hospitality Report (February), 4-17. I

Faulkner, B. (2001). Towards a framework for tourism disaster management. Tourism Management 22, 135-147. http://dx.doi.org/10.1016/S0261-5177(00)00048-0

Fundación Hostelería de Espana (2013): Los sectores de la hostelería 2011. Pozuelo de Alarcón (Madrid).

Gartzia, L.; Ryan, M. K.; Balluerka, N.; Aritzeta, A. (2012). Think crisis-think female: Further evidence. European 
Journal of Work \& $\quad$ Organizational Psychology $21 \quad$ (4), 603-628. http://dx.doi.org/10.1080/1359432X.2011.591572

González-Herrero, A.; Pratt, C. (2007). Preventive Marketing for Crisis Communication in Tourism: Management strategies in the USA and Spain. Journal of Communication Management 3 (1).

Graf-Riemann, L. (2011). Fettnäpfchenführer Spanien. Wie man den Stier bei den Hörnern packt. Meerbusch: Conbook Medien.

Henderson, J. C. (1999). Managing the Asian Financial Crisis: Tourist Attractions in Singapore. Journal of Travel Research 38, 177-181. http://dx.doi.org/10.1177/004728759903800212

Henderson, J. C. (2007). Tourism Crises: Causes, Consequences and Management. Oxford: Butterworth-Heinemann.

Herbane, B. (2010). Small business research: Time for a crisis-based view. International Small Business Journal 28 (1), 43-64. http://dx.doi.org/10.1177/0266242609350804

Johnson Tew, P.; Zhen, L.; Tolomiczenko, G.; Gellatly, J. (2008). SARS: lessons in strategic planning for hoteliers and destination marketers. International Journal of Contemporary Hospitality Management 20 (3), 332-346. http://dx.doi.org/10.1108/09596110810866145

Kash, T. J.; Darling, J. R. (1998). Crisis management: prevention, diagnosis and intervention. Leadership \& Organization Development Journal 19 (4), 179-186. http://dx.doi.org/10.1108/01437739810217151

Messe Basel. (2003). Messe Schweiz reicht Beschwerde gegen SARS-Verfügung des BAG ein. http://www.sinoptic.ch/textes/sante/2003/20030515_BS.messe_baselworld.pdf .

NN. (2009). Overcoming challenges in employment, housing and education would help put Spain back on the road to recovery. OECD Observer (270/271), 79-80.

NN (2010): España en cifras 2010. Instituto Nacional de Estadística. Madrid.

Okumus, F.; Karamustafa, K. (2005). Impact of an economic crisis. Evidence from Turkey. Annals of Tourism Research 32 (4), 942-961. http://dx.doi.org/10.1016/j.annals.2005.04.001

Parsa, H. G.; Self, J. T.; Njite, D.; King, T. (2005). Why Restaurants Fail. Cornell Hotel and Restaurant Administration Quarterly 46 (3), 304-322. http://dx.doi.org/10.1177/0010880405275598

Pennington-Gray, L.; Thapa, B.; Kaplanidou, K.; Cahyanto, I.; McLaughlin, E. (2011). Crisis Planning and Preparedness in the United States Tourism Industry. Cornell Hospitality Quarterly 52 (3), 312-320. http://dx.doi.org/10.1177/1938965511410866

Pizam, A.; Fleischer, A. (2002). Severity vs. frecuency of acts of terrorism: Which has a larger impact on tourism demand. Journal of Travel Research 40 (3), 337-339. http://dx.doi.org/10.1177/0047287502040003011

Reilly, A. H. (1987). Are Organizations Ready for a Crisis? A Managerial Scorecard. Columbia Journal of World Business 25 (5), 79-88.

Rodriguez-Toubez; D.; Fraiz Brea, J. A. (2012). Desarrollo de una politica de gestión de crisis para desastres en el turismo. Tourism \& Management Studies 8, 10-18.

Sausmarez, N. de (2004). Malaysia's response to the Asian financial crisis. Journal of Travel \& Tourism Marketing 15, 217-231. http://dx.doi.org/10.1300/J073v15n04_01

Spillan, J.; Hough, M. (2003). Crisis Planning in Small Businesses. European Management Journal 21 (3), 398-407. http://dx.doi.org/10.1016/S0263-2373(03)00046-X

Taylor, J. B. (2009). The Financial Crisis and the Policy Responses: An Empirical Analysis of What Went Wrong. NBER Working Paper 14631. Cambridge, MA: National Bureau of Economic Research.

Vargas-Sánchez, A. (2014). España vs Portugal: la imagen de ambos países y su evolución en tiempos de crisis. Tourism \& Management Studies 10 (Special Issue), 140-149. 